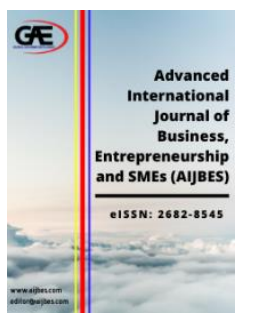

\author{
ADVANCED INTERNATIONAL JOURNAL OF \\ BUSINESS, ENTREPRENEURSHIP AND SMES \\ (AIJBES) \\ www.aijbes.com
}

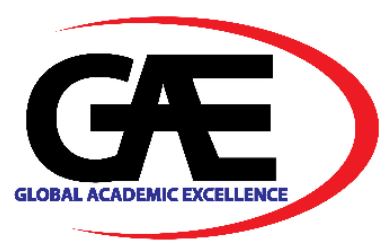

\title{
FACTORS INFLUENCING THE BEHAVIORAL INTENTION OF INDONESIAN GENERATION Z TO USE A NEW C2C E- COMMERCE PLATFORM CALLED INSTAGRAM SHOP
}

\author{
Gevani Syakinah Putri ${ }^{*}$, Ira Fachira ${ }^{2}$ \\ 1 School of Business and Management, Institut Teknologi Bandung \\ Email: gevani_syakinah@sbm-itb.ac.id \\ 2 School of Business and Management, Institut Teknologi Bandung \\ Email: Ira@sbm-itb.ac.id \\ * Corresponding Author
}

\section{Article Info:}

Article history:

Received date: 20.06 .2021

Revised date: 12.07 .2021

Accepted date: 02.08.2021

Published date: 01.09.2021

To cite this document:

Putri, G. S., \& Fachira, I. (2021). Factors Influencing the Behavioral Intention of Indonesian Generation Z to Use A New C2C E-Commerce Platform Called Instagram Shop. Advanced International Journal of Business, Entrepreneurship and SMEs, 3 (9), 123-131.

DOI: $10.35631 / \mathrm{AIJBES} .39009$.

\begin{abstract}
:
Most of Generation $\mathrm{Z}$ is being influenced by Instagram to shopping online. Additionally, Instagram now launched Instagram Shop to make users feel the easiness to shop within the application. This paper will identify which factors that can influence Indonesian Generation Z's behavioral intention to use Instagram Shop to purchase a product since the population in Indonesia is dominated by Generation Z. This fact would allow Instagram Shop or any other e-commerce leaders to have a deeper understanding and make an improvement on their marketing strategy in order to make the users satisfied. This paper will focus on the behavioral (Theory of Planned Behavior) and readiness to accept new ideas (Consumer Innovativeness) as factors in intention to use Instagram Shop of Indonesian Generation Z. Quantitative approach with spreading the questionnaire to 400 respondents as the minimum number will be used for the
\end{abstract} research.

Keywords:

Instagram Shop, Generation Z, Theory of Planned Behavior, Consumer Innovativeness

This work is licensed under CC BY 4.0

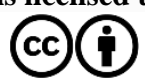




\section{Introduction}

Online shopping through e-commerce platforms is one of the growing activities across the world. Especially in the pandemic situation, people are being suggested to stay at their house and lockdown also being applied in most countries in the world to prevent the spread of the

COVID-19 virus. In Indonesia, people tend to do shopping online through e-commerce with a $66 \%$ increase from $24 \%$ as what survey result from DBS Asian Insights (Widjaja \& Sim, 2020). The platform of e-commerce is one of the most used by online shoppers. Bloomenthal (2020) define e-commerce as a place or online market for individuals and organizations to do online trade over the internet. In Indonesia, Bukalapak, Shopee, and Tokopedia are best three and most popular C2C (customer-to-customer) e-commerce platform (Ecommerceiq, 2018).

By this pandemic situation occurred Instagram to try to use this opportunity to make their new feature product into an e-commerce. This specific feature is called Instagram Shop. The feature has a purpose to help the businesses that currently using Instagram who is selling their product to be easier and provides easiness in online shopping (Instagram Business, 2020). Instagram Shop combining its existing feature such as Live Shopping, Explore Brands, IGTV, and shopping from creators into one place in the Instagram Shop section of its application.

In Indonesia, Instagram is in the fourth rank as the most used social media (Kemp, 2020). In 2017, 45 million people in Indonesia was detected using Instagram and categorized as being the largest user in the Asia Pacific (Ganesha, 2017). Those users are also increasing in 2018 where it is being dominated by Generation $\mathrm{Z}$ for a percentage calculated for approximately $75 \%$. Instagram is being the most prefer social media platform by Generation $\mathrm{Z}$ as revealed by Bradstreet on Loveland, (2017). Especially in buying a product, the generation is being more impulsive after seeing a product on Instagram specifically for women (Djafarova \& Bowes, 2021). This generation is popular by their image as "Digital Natives" since they were born where the technology is already been sophisticated. In Indonesia itself, the population is dominated by Generation $\mathrm{Z}$ with a total of 75 million people (Bappenas, 2020), and this data information indicated that Generation $\mathrm{Z}$ also will have an important role to grow the future image of Indonesia. Taylor \& Strutton (2016) reveal that since this generation being called as Digital Natives, they are also predicted will be a dominant segment in the e-commerce market. So, that is why it is important to be reasearch with potential and powerful generation for new Instagram Shop feature.

This research aims to identify what are factors influencing Indonesian Generation Z's behavioral intention to use this new feature called Instagram Shop. E-commerce Adoption Model by Crespo \& Bosque (2008) will be used in the research. Even though this generation can be easily adopting any new technology, the generation will not be willing to use the technology easily since they would have some factors that can influence their action to use new technology. The model or attributes in E-commerce Adoption Model can identify what factors that influence Generation $\mathrm{Z}$ intention to use the new Instagram Shop through an extended framework of Theory of Planned Behavior (attitude, subjective norm, perceived behavioral control, and intention) and with Customer Innovativeness (innovativeness - general and innovativeness - new technology) (Crespo \& Bosque, 2008). By knowing what factors 
Volume 3 Issue 9 (September 2021) PP. 123-131 DOI 10.35631/AIJBES.39009

influence Generation $\mathrm{Z}$ in Indonesia to use or adopt Instagram Shop, it will help the ecommerce platform or future online shop in Instagram to understand and decide what the suitable strategy to attract Generation $\mathrm{Z}$ in the usage of e-commerce technology as the future domination user of e-commerce.

\section{Literature Review}

\section{Concept of E-Commerce}

E-commerce or electronic commerce is a platform or a place where has some activities on it such as trade a variety of products, digital information delivery, as a marketing place, online auctions, and a lot more (Išoraitė \& Miniotienè, 2018). Another definition explained by Khan (2016) e-commerce is a buy-and-sell activity on the internet, where people there can make a comparison regarding the specifications and updates of its product before the buyer make a purchase.

E-commerce has different types of formats. The first type is based on the transaction method (Nemat, 2011):

a. B2B E-Commerce (Business-to-Business) where the transaction happens between businesses

b. B2C E-Commerce (Business-to-Consumer) where the transaction happen when businesses as the seller and consumer (organizations or individual) as the end buyer

c. C2B E-Commerce (Consumer-to-Business) where the consumer as individuals are offering or providing the product to a business on the internet.

d. C2C E-Commerce (Consumer-to-Consumer) where both the consumers (as a buyer or a seller) doing transactions and trading through a third-party platform to facilitate them in doing so.

The second type of e-commerce is based on the medium which is called m-commerce or Mobile Commerce. Mobile Commerce is commerce where the communications as well as the transaction being held on mobile devices for example in computer, laptop, and mobile phones. Other than that, m-commerce is using a wireless connection to the internet (Mousa Jaradat \& Al Rababaa, 2013).

\section{C2C E-Commerce}

Nemat, (2011) defines that $\mathrm{C} 2 \mathrm{C}$ e-commerce as e-commerce where the activities being conducted in the third-party platform and both consumer (as a buyer or a seller) can be able to occur trading over the internet. Wahyudiyono (2017) explains in Indonesia, the C2C ecommerce that existed is divided into 2 types which are marketplace $\mathrm{C} 2 \mathrm{C}$ and classified model.

a. Marketplace $\mathrm{C} 2 \mathrm{C}$ is an e-commerce platform that provides both places to promote the product that is sold by the buyer and also the transaction or digital payment method.

b. The classified model is e-commerce that provides a place for the seller to display their product to be sell and being seen by the buyer but does not offer a place to make transactions inside the platform. So, the transaction has to be done outside the platform based on the buyer and seller agreement. 
Volume 3 Issue 9 (September 2021) PP. 123-131

DOI 10.35631/AIJBES.39009

In this research, Instagram Shop can be categorized as classified model e-commerce since the application has not provided a place for the buyer and seller to make transactions inside the application.

\section{Generation Z}

A generation is a set of groups based on the history of culture, were to identify which this person belongs to a specific generation, the closest social form is needed to be identified in terms of sharing characteristics or culture (Parry \& Urwin, 2011). Other than that, generation

also can be explained as a group that has the same years of birth, age, or sharing similar characteristics (Kupperschmidt, 2000). Hawkins \& Mothersbaugh (2010) categorized Generation $Z$ as one of the generations they are who were born between $1995-2005$. Generation $\mathrm{Z}$ is also being called Mobile Generation because around 93.9\% of them are already being connected to be internet (Alvara Research Center, 2020). The generation getting used to the internet because they were born when the internet already been sophisticated and also play an important role in their lives. In terms of online shopping, it is being predicted that Generation $\mathrm{Z}$ is going to be a dominant consumer for e-commerce (Taylor and Strutton, 2016).

\section{E-Commerce Adoption Model}

The E-commerce Adoption Model that being used in this research is a model that is developed by Crespo and Bosque (2008) where it is an extended model of the Theory of Planned Behavior with Customer Innovativeness variables. The variables that are measured in this model are attitude, subjective norm, perceived behavioral control, innovativeness - general, and innovativeness - new technology. Crespo and Bosque made this model and reveal that innovativeness variables have an important role in user's adoption of online shopping and ecommerce (Crespo and Bosque, 2008).

\section{Theory of Planned Behavior}

Theory of Planned Behavior is an extended version of Theory of Reasoned Action where in TPB model behavioral control concept is included as one of the main variable on the model (Schifter \& Ajzen, 1985). The theory have 3 main variables of intention to whether perform a behavior or not which are attitude, subjective norm, and perceived behavioral control.

\section{Attitude}

Attitude is an individual's consideration regarding their belief and its impact on performing a behavior (Fishbein and Ajzen, 1977). This variable is part of an individual's evaluation of whether the object or behavior is having positive or negative effects. Gangwal \& Bansal (2016) reveal that attitude variables have a significant influence among variables in the Theory of Planned Behavior to predict adoption action towards e-commerce usage of Indian customers.

\section{Subjective Norm}

Subjective norm can be defined as perceptions of individuals towards particular behavior that is influenced by other people such as family, friends, relatives, or even by his or her behavior (Fishbein \& Ajzen, 1973). Crespo and Bosque explain that subjective norms appear from 2 factors where the first one is the individual connected with other's people perceptions and the second is the motive of the individual affected by other people's hopes to perform a particular 
Volume 3 Issue 9 (September 2021) PP. 123-131

DOI 10.35631/AIJBES.39009

behavior. On Gangwal and Bansal (2016), they identify that Indians considering other people's opinion like friends, parents, and even colleagues to adopt e-commerce technology.

\section{Perceived Behavioral Norm}

The variable can explain to researchers about individual's reactions to the easiness and difficulties in performing a particular behavior that they feel interested in (Ajzen, 1991).

\section{Customer Innovativeness}

Innovativeness is the level of an individual when they are ready or even willing to adopt new ideas and their ability to decide if they can adopt based on the experiences with the group (Rogers and Shoemaker, 1971).

\section{Innovativeness - General}

Hurt et al. (1977) explain that innovativeness general is a readiness of an individual or willingness to change a character of an individual based on their cognitive approach or based on their personality. In general, people's readiness for innovations, new products, or other new ideas is being influenced by their cognitive style (Crespo and Bosque, 2008). This aspect can measure or identify what personality characteristics of an individual when it comes to accepting new ideas in general.

\section{Innovativeness - New Technology}

Domain-Specific Innovativeness is a predisposition of an individual to accept and adopt new ideas which are in the specific interest of the individual (Citrin et al., 2006). By measuring this aspect, it can explain more result regarding the readiness of individual towards narrow ideas or specific area since innovativeness - general have limitations in the measurement which is only from the cognitive aspect.

Previous studies that have been conducted by some researcher such as Citrin et al. (2006), Huotilainen et al. (2006), and Flynn \& Goldsmith (1993), the example of an object of their studies are adopting online shopping, rock music adoption, and individual readiness in trying new foods. Robertson (1971) explains that an individual can adopt within a different category that is given and among related product classes.

In this journal, the researcher adopted the term from Crespo and Bosque's model in 2008 where they state domain-specific innovativeness as innovativeness - new technology since the focus of the model is on new e-commerce technology.

\section{Methodology}

Several steps must be done first before the researcher moving further in gathering the final data and analysing for the result. First, the researcher must clearly define which problem that the research will focus on, research objectives and questions, also the scope and limitation of this research. For this research, the researcher wants to identify what factors that influencing Indonesian Generation Z's intention to use or adopt a new e-commerce platform called Instagram Shop. The researcher decided to focus on Indonesian Generation $\mathrm{Z}$ who were born between 1995-2005 and domiciled in Indonesia. Second, reviewing previous studies to support 
Volume 3 Issue 9 (September 2021) PP. 123-131 DOI 10.35631/AIJBES.39009

and understanding deeper about theories that being used in the research is needed as well as choose the suitable construct to generate the best result.

This research also will use a quantitative approach as the methodology and using an online questionnaire that will be spread widely to this research target respondents. To have an accurate result and achieve the standard number of respondents, the researcher uses Slovin's Formula to have a minimum number of respondents that the researcher must collect. After calculating the number with the total population of Gen $\mathrm{Z}$ in Indonesia is 75 million people based on Bappenas (2020) and using a 95\% confidence level, as well as 5\% margin of error, it is generated that 400 respondents needed to be collected as the minimum number.

The data collected later will be analyzed with descriptive statistics as well as the Structured Equation Modelling - Partial Least Square. The model analysis will use the SmartPls

application. Before the researcher spread the questionnaire widely, a pilot test or study should be done first to see if the items used as the questions are whether valid or not and reliable or not. In the pilot study, the questionnaire will be shared with a minimum of 30 respondents.

\section{Conceptual Framework}

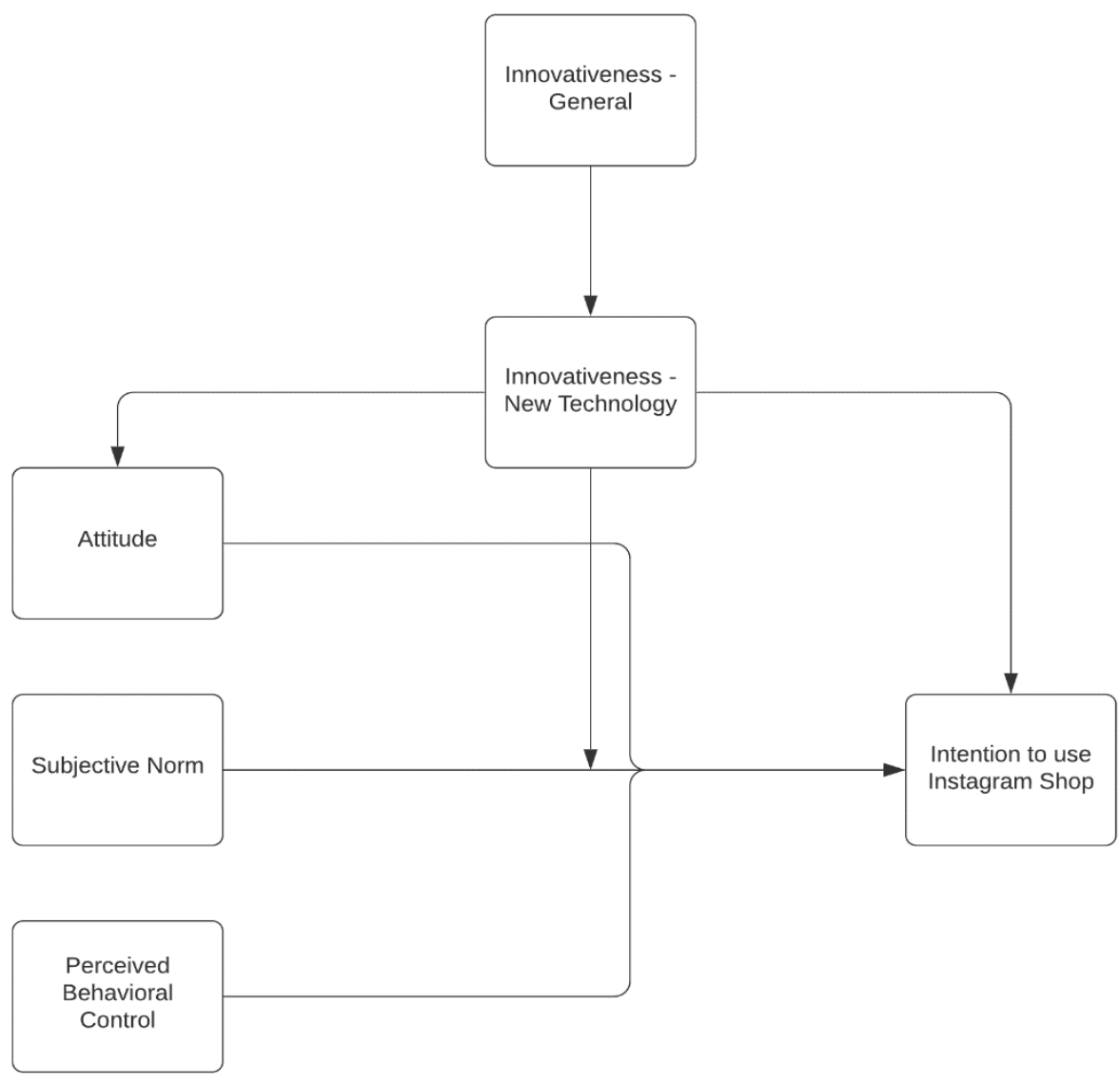

Figure 1: Conceptual Framework 
Volume 3 Issue 9 (September 2021) PP. 123-131

DOI 10.35631/AIJBES.39009

From the conceptual framework above, we can see that some variables can be a factor of Indonesian Generation Z's intention to use or adopt the Instagram Shop as the new feature. 5 main factors can generate a result which factors that being the most stand out to make individuals feels influenced to intent to use new e-commerce technology. In the framework, there are independent variables which are attitude, subjective norm, perceived behavioral control, and innovativeness - general. For innovativeness - new technology, the variable can be an independent and moderating variable. Innovativeness - new technology as moderating variable, where it is the moderate subjective norm and intention variables. And lastly, the intention to use Instagram Shop is the dependent variable.

On the conceptual framework, there is a moderating variable which is innovativeness - new technology between the relationship of subjective norm and intention. Based on Midgley and Dowling (1978) they reveal that if an individual have high innovativeness in accepting new ideas, it means they can make a decision without considering other people's opinion as a third

party. So, Crespo and Bosque (2008) also assume in developing the framework that innovativeness - new technology can moderated the relationship of subjective norm and intention. As align with the purpose of moderating variable is making the moderated variable is weaken or stronger.

The E-commerce Adoption Model is a model that identifies based on individual aspects of ecommerce technology. By knowing and measure each factor on the model, it will help the researcher analyze behavior of an individual of Generation $\mathrm{Z}$ when it comes to adopt new ecommerce platform and share some strategy what e-commerce business have to do in the future when Generation $\mathrm{Z}$ will be the majority target market.

\section{Conclusion}

In this research, the researcher intends to analyze and understanding which factors can influence most Indonesian Generation Z's intention to use a new e-commerce platform called Instagram Shop to buy a product. This conceptual paper will be the proposed model as well as the methodology for future research. This research must collect respondents to get an accurate and deeper result as well as the explanation using a quantitative approach. The final questionnaire will be spread widely to a minimum of 400 respondents that fulfil the criteria. After the data being gathered, the researcher will make a solution and some strategy which in hope can be helpful for e-commerce business actor to attract their target market, specifically Generation $\mathrm{Z}$ in Indonesia.

\section{References}

Ajzen, I. (1991). The Theory of Planned Behavior Organizational Behavior and Human Decision Processes. Organizational Behavior and Human Decision Processes, 50(2), 179-211.

Alvara Research Center. (2020). The Battle Of Our Generation: Indonesia Gen Z and Millennial Report 2020, 134. Retrieved from https://alvara-strategic.com/indonesiagen-z-and-millenial-report-2020/

Citrin, A. V., Sprott, D. E., Silverman, S. N., Stem, D. E., Citrin, A. V., Sprott, D. E., \& Silverman, S. N. (2006). Adoption of Internet shopping: the role of consumer 
Volume 3 Issue 9 (September 2021) PP. 123-131 DOI 10.35631/AIJBES.39009

innovativeness Adoption of Internet shopping: the role of consumer innovativeness. Industrial Management \& Data Systems, 100(7), 294-300.

Crespo, Á., \& Bosque, I. (2008). The effect of innovativeness on the adoption of B2C ecommerce: A model based on the Theory of Planned Behaviour. Computers in Human Behavior, 24(6), 2830-2847. doi:10.1016/j.chb.2008.04.008

Djafarova, E., \& Bowes, T. (2021). 'Instagram made Me buy it': Generation Z impulse purchases in fashion industry. Journal of Retailing and Consumer Services, 59(xxxx), 102345. doi:10.1016/j.jretconser.2020.102345

Fishbein, M., \& Ajzen, I. (1973). Attribution of responsibility: A theoretical note. Journal of Experimental Social Psychology, 9(2), 148-153. doi:10.1016/0022-1031(73)90006-1

Flynn, L. R., \& Goldsmith, R. E. (1993). A validation of the goldsmith and hofacker innovativeness scale. Educational and Psychological Measurement, 53(4), 1105-1116. doi:10.1177/0013164493053004023

Gangwal, N., \& Bansal, V. (2016). Application of decomposed theory of planned behavior for M-commerce adoption in India. ICEIS 2016 - Proceedings of the 18th International Conference on Enterprise Information Systems, 2(Iceis), 357-367. doi:10.5220/0005627503570367

Hawkins, D. I., \& Mothersbaugh, D. L. (2010). Consumer Behaviour:Building Marketing Strategies. Retrieved from www.mhhe.com

Huotilainen, A., Pirttilä-Backman, A. M., \& Tuorila, H. (2006). How innovativeness relates to social representation of new foods and to the willingness to try and use such foods. Food Quality and Preference, 17(5), 353-361. doi:10.1016/j.foodqual.2005.04.005

Išoraite, M., \& Miniotienè, N. (2018). Electronic Commerce: Theory and Practice. IJBE (Integrated Journal of Business and Economics), 2(2), 73. doi:10.33019/ijbe.v2i2.78

Khan, A. G. (2016). Electronic Commerce: A Study on Benefits and Challenges in an Emerging Economy. Type: Double Blind Peer Reviewed International Research Journal Publisher: Global Journals Inc, 16(1).

Kupperschmidt. (2000). Multigenerational employee. Health Care Manager.

Loveland, E. (2017). Instant Generation. Journal of College Admission, 235, 34-38.

Midgley, D. F., \& Dowling, G. R. (1978). Innovativeness: The Concept and Its Measurement. Journal of Consumer Research, 4(4), 229. doi:10.1086/208701

Mousa Jaradat, M.-I. R., \& Al Rababaa, M. S. (2013). Assessing Key Factor that Influence on the Acceptance of Mobile Commerce Based on Modified UTAUT. International Journal of Business and Management, 8(23). doi:10.5539/ijbm.v8n23p102

Nemat, R. (2011). Taking a look at different types of e-commerce. World Applied Programming, 1(June), 100-104.

Parry, E., \& Urwin, P. (2011). Generational Differences in Work Values: A Review of Theory and Evidence. International Journal of Management Reviews, 13(1), 79-96. doi:10.1111/j.1468-2370.2010.00285.x

Schifter, D. E., \& Ajzen, I. (1985). Intention, Perceived Control, and Weight Loss. An Application of the Theory of Planned Behavior. Journal of Personality and Social Psychology, 49(3), 843-851. doi:10.1037/0022-3514.49.3.843

Taylor, D. G., \& Strutton, D. (2016). Does Facebook usage lead to conspicuous consumption?: The role of envy, narcissism and self-promotion. Journal of Research in Interactive Marketing, 10(3), 231-248. doi:10.1108/JRIM-01-2015-0009 
Volume 3 Issue 9 (September 2021) PP. 123-131 DOI 10.35631/AIJBES.39009

Wahyudiyono. (2017). TRANSAKSI E-COMMERCE MASYARAKAT JAWA TIMUR ECOMMERCE TRANSACTION OF EAST JAVA COMMUNITY Abstrac t. Jurnal Komunikasi, Media Dan Informatika, 6(3).

Widjaja, C. C., \& Sim, A. (2020). COVID-19's Impact on Indonesian Consumers Accelerating shifts in consumer behaviour. DBS Asian Insights: Sector Briefing 91, (September). 